\title{
COLLABORATIVE ECONOMY AS AN INDICATION OF SUSTAINABLE CONSUMPTION IN RESULTS OF EXAMINED PEOPLE
}

\author{
Agnieszka Tłuczak, ${ }^{1}$ Sabina Kauf ${ }^{2}$
}

\begin{abstract}
Sustainable consumption takes inspiration from the newest trends in economics which is a collaborative economy. This type of economy changes the model of organization and distribution based on sharing, using and creating together. The basic aim of this study is pointing out a purpose of a collaborating economy in the accomplishment of sustained consumption rules and in a conscious and self-motivated limit of personal consumption to the purpose of co-sharing. This task is going to be achieved with empirical verification of consumers behavior based on answers to a questionnaire. Research has confirmed the suggested hypothesis. People want to attend in collaborative consumption, which is positively correlated with the level of self-satisfaction from life and income. The results presented in this paper shouldn't be treated as final, because it was pilot research.
\end{abstract}

JEL Classification Numbers: E03, E21, E29; DOI: http://dx.doi.org/10.12955/cbup.v5.969

Keywords: collaborative, consumption, co-sharing, sustainable.

\section{Introduction}

The last two decades of $21^{\text {st }}$ century mark themselves in the growth of the meaning of consumption described as sustainable and being the answer of consumers to the growing social and environmental issues. It is said that it has its source in a report from Bruntland which sketched directions of development of the modern economy systems (Our 1987, p. 16).

Sustainable consumption is in the center of concern of the economy, studies about rational managing limited resources and alternative ways of using it (Sowell 2000; p. 66, Mont, Plepys 2008, p. 532). It is an alternative for consumerism, spare consumption that crosses a level which is necessary to appease people's needs (Baudrillard 2005). It means that optimal, conscious and responsible use of available natural resources, goods and services according to rules of sustainable development. We are able to see it in the reorientation of behaviors, change of egocentric basis in an egocentric direction and purchasing decisions which include the needs of others and the environment. Sustainable consumption is also a conscious limit of consumption - anti-consumption which doesn't mean quitting from satisfying your needs but making it more rational, responsible and ethical (Binkley \& Littler, 2011; Iyer \& Muncy, 2009; Chatzidakis \& Lee, 2013, Hogg et al., 2009; Shaw \& Newholm, 2002).

Sustainable consumption takes inspiration from the newest trends in economics which is a collaborative economy which changes the model of organization and distribution based on sharing, using and creating together (Botsman \& Rogers, 2010, Pearson, 2014; Ozanne \& Ballantine, 2010). The basic aim of this study is pointing out a purpose of a collaborating economy in the accomplishment of sustained consumption rules and in a conscious and self-motivated limit of personal consumption to the purpose of co-sharing. This task is going to be achieved with empirical verification of consumers behavior based on answers in a questionnaire.

\section{Collaborative economy as an element of sustainable consumption - literature review}

The problem of sustainable consumption gets more and more attention. Its main idea is increasing the disequilibrium between using resources and their availability on earth and the big differentiation of the standard of living among people who live in regions with different rates of growth (Evans 2011; Lorek \& Fuchs, 2014). This is evident in gained behaviors which support using products that consummate basic needs and minimalize the abortion of natural resources. The increased prevalence of sustainable consumption opens up wide abilities to creating new business models based on rules of the collaborative economy. This has been started in the new technology era with easy access to the internet. It is defined as sharing, bartering, lending and ranting of products and technology (Botsman \& Rogers 2010; Schor \& Thompson 2014b, pp. 4 -6). It is opposite to the usual business economy which leads to having and getting, the expression of my own "me" and identification with objects (Kleine et al., 1995, p. 328). Schor names the collaborative economy a social, sustainable innovation with the ability to improve and develop new technologies for communication and informatics and web

\footnotetext{
${ }^{1}$ Opole University, atluczak@uni.opole.pl

${ }^{2}$ Opole University, skauf@uni.opole.pl
} 
communities (Schor, 2011). A Collaborative (or sharing) economy is meant to get relationships with strangers through cyber platforms (Schor,2015).

The author of "sharing economy" is M. Weltzman, the economist who used it in 1984 for the first time in the book named "The share economy." This saying means "collaborative consumption made by the activities of sharing, exchanging and rental of resources without owning the goods (Lessing, 2008). Collaborative consumption shows the tendencies of consumers to involve themselves into systems and consumption webs, which gives them access to products and services without paying obligatory fees that come from property of law (Botsman \& Roger, 2010; Gansky, 2010). It is a symptom of common digitization and actualize era of prosumers (Ritzer \& Jurgenson, 2010; Toffler, 1980). Nowadays almost every consumer has an ability to become a producer by only using commonly available web platforms, which give the consumers a variety of opportunities to express their identities (Belk 2013a, Belk 2013b). It means the subject of a sharing economy are resources, services and transport (BlaBlaCar, Turo, Uber) accommodation and space (Airbnb, Landshare, JustPark), abilities and time (Killshare, Skilltrade, Khan Academy) and other resources like for example tools.

The Internet and social media do not guarantee the sense of independence. Web connections have contributed to creating a new form of community where property doesn't have any economic value. What is very important is affiliation, trust and devotion. In an economical context collaborative consumption is an economical model sustained by the common use of products (ex. physical good or service) in webs C2C and B2C (Hamari et al., 2015, p.1). In the first case those webs have been coordinated through social websites which help in social interaction (Liand \& Turban, 2011), in the second case through an agent. In every single one of them, the main condition is specific information about the reputation on the social website of people from the exchange. R. Bosman and R. Rogers highlight that social websites (Facebook, Twitter, Freecycle) increase the ability of consumers to exchange and cooperate and not see any risk (Botsman \& Rogers, 2010).

Collaborative consumption is social movement against isolation, separation and grouping, which keeps getting more and more popular among consumers, especially young, because it precisely gives them their basic needs: low prices, individualism, comfort. It is possible thanks to the effective collaboration free sources (ex. car, flat, abilities). Even though collaboration isn't based on sharing properties, it needs transaction mechanisms $\mathrm{C} 2 \mathrm{C}$, like for example: making bookings (of a bike, car) or payments. The sharing economy is not always only kindness and charity, it's also profit that matters and the need of saving and confrontation with ability to get profits is the thing that makes it work. It will be possible according to decreasing costs of transactions made with the help of the Internet. Just like Rifkin said: in the future, there will be community of zero final cost, in which the costs of using a certain good through next subjects will be very low (Rifkin, 2015). Through Internet platforms it will be possible to widen a size of users of a goods and Internet services will earn on advertisements or payments for help. Even though in the literature of the subject there is highlighted the positive role of consumption in promoting "positive" materialism which means connection to the meaning of quality of goods, their background, kind of used sources and extend a cycle of using a product (Schor, Thompson 2014b, p.14) it is hard today to describe how collaboration is really promoting the matter of sustainable consumption. As Schor said widely shared beliefs about the good influence of the sharing economy and anti-consumption show the basis of consumers against sustainable consumption.

\section{Methodology and results of studies}

The main subject of study is the collaborative economy, which makes up an integral element of sustainable development. Authors of this theory think that collaboration is shown in resignation, reduction and reuse of goods shows sustainable style of living. It was established additional that consumers using sharing are more pleased from their life and they spent their money more rationally. Those assumptions make us enunciate two hypothesis":

\section{H1: Collaborative consumption is positively connected to happiness in life}

$\mathrm{H} 2$ : Sharing economy is positively connected with how much we have.

Verification of the hypothesis was made based on a questionnaire made by group of professors I. Balderjahn from University of Potsdam. The research was conducted during spring 2016 in Poland, in opolskie voivodeship, on 250 randomly chosen and connected people. According to age, sex, and 
income, the research was compatible to the structure of the general population (tab 1.). This research was a kind of pilot. These were pilot studies, the location was chosen deliberately.

Table 1: Demographic profiles of the samples

\begin{tabular}{|c|l|c|c|c|c|}
\hline \multicolumn{2}{|c|}{ Age } & up to 30 years old & from 30 to 40 & from 40 to 50 & more than 50 \\
\hline \multirow{2}{*}{ Gender } & Female & $51 \%$ & $48 \%$ & $56 \%$ & $51 \%$ \\
\cline { 2 - 6 } & Male & $45 \%$ & $52 \%$ & $44 \%$ & $49 \%$ \\
\hline
\end{tabular}

Source: Author.

\begin{tabular}{|c|c|c|c|}
\hline & & self-happiness & $p$-value \\
\hline & I'd rather borrow this product from friends & 0,7070 & $0,213^{*} 10^{-6}$ \\
\hline & I'd rather share this with others & 0,5732 & $0,146 * 10^{-3}$ \\
\hline & I'd rather lend it to someone & 0,7101 & $0,001 * 10^{-8}$ \\
\hline
\end{tabular}

Table 3: Correlation between will to share and self happiness level of income

\begin{tabular}{|l|l|l|l|}
\hline & \multicolumn{1}{|l|}{ Income } & p-value \\
\cline { 2 - 4 } & I'd rather borrow this product from friends & 0,870416 & $0,041 * 10^{-8}$ \\
\cline { 2 - 4 } & I'd rather share this with others & 0,804301 & $0,621^{*} 10^{-9}$ \\
\hline & I'd rather lend it to someone & 0,792103 & $0,102 * 10^{-4}$ \\
\hline
\end{tabular}

The gained results supported the made hypothesis. Collaborative consumption is correlated to the level of self-happiness from living of the studied people. Additionally, what's worth more attention is a fact that it is a positive correlation, so as the will to share a good of stabile use is bigger, the more selfhappy is the studied person.

As the analysis have shown, answers according to characteristics of studied people are differentiations between attending in the sharing economy and the level of self-happiness between male and female. Male mark their level of self-happiness higher than female, but their will to share is smaller. Among the described items which the studied people pointed as those that they are able to share, in the first place was a drill, then snow skis, then a washing machine and finally a camera.

Income that divides polish community is also positively correlated with will to share. Often having more income lead to buying additional, not necessarily useful products. Among the studied people there is bigger will to leave their money in single use in the share economy. Those people think that rather than having something, they would like to have a free access to some other goods. Even though if they already have something they are not necessarily connected to it, but they can share it with other people.

As a main reason of being part of sharing economy, the studied people say it's their saving $(32 \%)$, ability to meet other people (26\%) and a will to help others. Their attitude to property changes and approval of services and applications which are based on sharing rule. More and more people see how important is access to goods and not actually having it. Some part of them is doing it because of economic reasons, but some are fully into the idea of sharing it (goods).

\section{Summary}

There is a new trend in Western Europe countries, it is a continued new idea in the Polish country. The consciousness of limit of natural resources should incline consumers to share certain goods of permanent use (and not only those). The sharing economy should make consumers feel positive and they show this with a connection to certain motivations. More of the studied people agree that it is more affordable to use someone else's goods than having it for themselves. Consumers see real advantages from someone's resources in place of actually having it for example savings, feeling comfortable and elasticity: empowering social connections, positive influence to the environment, and a bigger satisfaction from interaction. Research has confirmed the made hypothesis. The will to participate in collaborative consumption is positively correlated with a level of self-satisfaction from life and income. Our theoretical and empirical assumptions give basic ideas to making a study directed 
to Polish consumers. The results presented in our work should be treated as final because the research we made was only a pilot and in the future authors are going to widen the presented topics.

\section{Final Comments}

Sustainable consumption takes inspiration from the newest trends in economics which is a collaborative economy. It is a new trend in Western Europe countries, The main reason of being part of sharing economy, the studied people say it's their saving (32\%), ability to meet other people (26\%) and a will to help others.

\section{References}

Baudrillard, J. (2005). The Consumer Society: Myths and Structures, Sage Publishing. London. Belk, R. (2013a). Extended self in a digital world. Journal of Consumer Research, 40, 477-500.

Belk, R. (2013b). Sharing versus pseudo-sharing in Web 2.0. The Anthropologist, 4 (2), 13 - 20.

Binkley, S., Littler, J. (2011). Cultural Studies and ant-consumerism. Rotlegle. New York.

Botsman, R., Rogers, R. (2010). What's Mine Is Yours: The Rise of Collaborative Consumption. Harper Business.

Brundtland Commission. (1987). Our common future: Report of the World Commission on Environment and Development. UN Documents Gatheringa Body of Global Agreements.

Chatzidakis, A., Lee, M. (2013). Anti-consumption as the Study of Reasons Against. Journal of Macromarketing. 33 (3), 190-203.

Evans, D. (2011). Thrifty, Green or frugal: Reflections on sustainable consumption in a changing economic climate. Geoforum. 42, 550-557.

Gansky, L. (2010). The Mesh. Why the Future of Business is Sharing. Portfolio/Penguin. London.

Hamari, J, Sjöklint, M., Ukkonen, A. (2015). The sharing economy: why people participate in collaborative consumption. Journal of The Association For Information Science and Technology. 67(9), 2047-2059.

Hogg, M. K., Banister, E. N., Stephenson, Ch. A. (2009). Mapping Symbolic (Anti-) Consumption. Journal of Business Research. 62 (2), 148-159.

Kleine, S. S., Kleine R. E., Allen, Ch. T. (1995). How is Possession "Me" or "Not Me"? Characterizing Types and an Antecedent of Material Possession Attachment. Journal of Consumer Research. 22, 327-343.

Liang, T. P., Turban, E. (2011). Introduction to the special issue social commerce: a research framework for social commerce. International Journal of Electronic Commerce. 16(2), 5 - 14.

Lorek, S., Fuchs, D. (2013). Strong sustainable consumption governance - precondition for a degrowth path?. Journal of Cleaner Production . 38(14), 36 - 43.

Lorek, S., Spangenberg, J. H.(2014). Sustainable consumption within a sustainable economy - beyond green growth and green economies. Journal of Cleaner Production. 63(14), 33 - 44.

Mont, O., Plepys, A. (2008). Sustainable consumption progress: should we be proud or alarmed?. Journal of Cleaner Production. 16(4), 531 - 537.

Ozanne L.K., Ballantine P.W, Sharing as a Form of Anti-Consumption? An Examination of Toy Library Users. „Journal of Consumer Behaviour" 2010, 9 (6), pp. 485-498.

Parsons, A. (2014). Putting the ' sharing ' back in to the sharing economy. Share The World's Resourceshttp://www.sharing.org/information-centre/articles/putting-\%E2\%80\%98sharing\%E2\%80\% 99-back-sharingeconomy (06.09.16).

Rajesh, I., Muncy, J. A. (2009). Purpose and Object of Anti-consumption, Journal of Business Research. 62 (2), 160 - 168.

Rifkin, J. (2015). The Zero Marginal Cost Society: The Internet of Things, the Collaborative Commons, and the Eclipse of Capitalism, St. Martin Press, New York.

Ritzer, G., Jurgenson, N. (2010). Production, consumption, prosumption: The nature of capitalism in the age of the digital 'prosumer'. Journal of Consumer Culture. 10,13 - 36.

Schor, J. (2014). Debating the Sharing Economy. Essay, The Great Transition Initiative. Tellus Institute.

Schor, J. B., Change, C. (2011). A Plentitude Economy.

Schor, J. B., Thompson, C. J. (2014). Sustainable Lifestyles and the Quest for Plenitude. Case Studies of the New Economy. Yale University Press.

Sowell, T., Ekonomia dla każdego. Wydawnictwo Fijor Publishing, Chicago-Warszawa.

Toffler, A. (1980). The third wave. New York: William Morrow and Company. Inc. Toffler The Third Wave 1980. 